\title{
Examination Performance of Students Trained with Modern Learing Tools
}

\author{
M. Sankar, R. Vasuki, G. Anadhi
}

\begin{abstract}
Purpose: The purpose of the present paper is to identify the role of A Study on Teaching Methods and school Students' performance in urban area. The factors of school performance such as teaching methods (exogenous variable) and school Students performance (Endogenous variable) are measured. The endogenous item is students' perception is measured as single.

Method: Overview technique was utilized in the investigation to gather the information; Structured Questionnaire was dispersed to 55 respondents of understudies (male and female). 05 Questionnaires were seen as unfilled so complete 50 respondents $(n=50)$. $C F A$ and $S E M$ were the factual apparatuses applied for the investigation in AMOS-21 to check the speculation of learn.

Findings: The study is portraying on positive and significant relation among the exogenous is level of teaching mathods and the endogenous is school students' performance.

Suggestion: The results display on the paper teaching methods and students perception. Limitations: Time period is another factor limitation for the study. Hence findings cannot be generalized.
\end{abstract}

Key words - school students' performance, Teaching Methods

\section{INTRODUCTION}

In this study we had to concentrate the level of university smart class like Teaching Methods and students perception. Most of the studies to explain students' perception to measure

the examination like GPA. The integer knowledge and skill oriented study and college environment and play for students

games for the example of volleyball, athletics, and cricket to refresh our mind. The primary role of theory to concentrate for play a vital role for better living (Battle \& Lewis, 2002). The company to expect more than output for our company role, maximum product for maximum gain to increase national economic (Saxton, 2000). The factors that influence most of the researcher to follow for respondents details (Gender, age, education, family income, Parents education) (Crosnoe, Johnson \& Elder, 2004). The most of the talent persons to explain that socio-economic concentrate students'

perception to measures for economic. Well being today economic one of the powerful and basic needs of human

Revised Manuscript Received on December 11, 2019

M. Sankar, Assistant Professor, Department Of Science and Humanities,,Bharath Institution Of Higher Education And Research,TamilNadu,India. Email: sankar06.phd@gmail.com

R. Vasuki, Assistant Professor, Department Of Science and Humanities,,Bharath Institution Of Higher Education And Research TamilNadu,India. Email: vasukiteacher@gmail.com

G. Anadhi, Assistant Professor, Department Of Science and Humanities, Bharath Institution Of Higher Education And Research TamilNadu,India. Email: anandhi5679@gmail.com wants (Adams, 1996). The economically weak students low results for our perceptions (US Department of Education, 2003).[1]-[4] Proclamation of the issue Numerous analysts investigated understudy's introduction (execution) by GPA and CGPA was found. In this articles pursued by Grade point esteem. A few analysts to looking at the quarterly, half yearly and every year to gather the student progress in required explore. The point of the present investigation was concentrate student's learning and result of the exhibition (test results) was determined by GPA.Conceptual

Author's Model

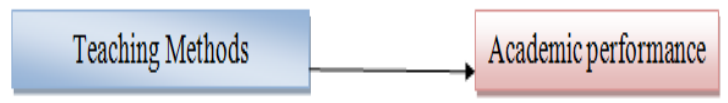

Fig.1. Theoretical Model

\section{REVIEW OF LITERATURE}

Education is one of the powerful tool in the world most of the country to create awareness about education. Education has changed our knowledge, skills, self confidence, and balance of our economic status to change of learnrs (Tsinidou, Gerogiannis, \& Fitsilis, 2010). The define of educational various from country to country culture difference (Michael, 1998). These societal has vital role of goal setting of students perception (Goddard, 2003). [4]-[7]

Who are professionally qualified students'femaledisplays better than maleperformance (Chambers \& Schreiber, 2004). Male and female and parents profession are positive contributor to student success (McCoy, 2005; Peng \& Hall, 1995). A research study which highlights the opinion of male and female, discusses that female students perform better when compared to male students.

Teaching Methods

Teaching methods related to teacher self methods. The limited studies published shows that have empirically investigate of the idea on academic performance have emphasized the concept's contextualized nature. Miller and Shih (1999) survey was 262 faculties about their perceptions of the differences in the analogous concept of academic severity levels between on-campus and off-campus courses. At their institution, off-campus courses are delivered electronically, or they are taught traditionally at a site off campus. 
Their survey characterize academic challenge in several ways: as demanding high achievement (Braxton, 1993), as challenging students to struggle for fineness (Unks, 1979), and as engaging students in active learning. The authors believed, however, that these perceptions alone were not strong enough evidence to suggest that the teaching for rigor was different between the two types of courses. The National Survey of Student Engagement (2012), often referred to as the NSSE, provides higher education institutions with students' reflections on their learning, including academic challenge, and on their participation in education-related programs and activities. [8]-[11]

Students is one of the fundamental asset of university, because the first person of the institution to produced economic under hold on our hand, but student management is basically arts, because each and every student measure the difficult to understand one person to other. Commonly to explain students is most powerful persons because to divide all job only students. Students performance has been measures our knowledge, practical skills, lab skills etc. The most of the educational institution measure only for students' examination like GPA and CGPA. Students' performance has been argued among teacher, employees, and Dean of the institution. Students' perception has been lots of study that sounds good. The previous findings explain work hard, education level of parents, previous university, family income and factors of self motivation have been positive outcome on the students GPA. The study on students' perception measure on GPA. The item that support affect student's performance Academic challenge. The results also show that academic challenge management students' performance is strong support.[12]-[16]

\section{OBJECTIVE OF THE STUDY}

1. To analyze the association amonglevel of Teaching Methods and students' performance.

\section{HypothesIs}

H1. There is positive relationamongTeaching Methods and Academic performance.

\section{NEED FOR THE STUDY}

- To think about the enlistment procedure.

- To study the HR polices and the working of HR office.

- To study how the opportunities are cleared and on what base the up-and-comers are enlistment for a specific employment.

- To recognize and recommend measures for the improvement of the enlistment programs.

- To learn about the enlistment techniques.

- To assess the enrollment the executives programs

\section{OBJECTIVES OF THE STUDY}

Primary objectives

- To study of effectiveness of recruitment process at "Yoho technologies pvt ltd".

\section{Secondary objectives}

- To analysis the satisfaction level of employees towards selection interview and some key consideration while interview.

- To find out the opinion of employees towards the training after final interview and offer letter procedure.

- $\quad$ To find whether the recruitment procedures and policies are satisfied by the employees.

\section{RESEARCH METHODOLOGY}

Research Design :Descriptive Research

Sample Size $\quad: 110$

Data Collection Method :Primary Data, Secondary Data

\section{RESULTS AND DISCUSSIONS}

\section{i. Chi-Square Test}

$\mathrm{Ho}=$ There is no significant different between the year of experience of employees with respected to the opinion about the present method followed by organization.

$\mathrm{H} 1=$ There is significant different between the year of experience in employees with respected to enhance the opinion about the present method followed by organization.

Chi-square test association difference between the year of experience inemployees with respected to enhance the opinion about the present method followed by organization.[17]-[20]

\section{Sample chi-square $\left(\mathbf{x}^{2}\right)=\sum\left(\underline{0}_{1}-\underline{F}_{4}\right)^{2}$}

$\mathrm{E}_{4}$

\begin{tabular}{|c|c|c|c|c|c|c|}
\hline \multicolumn{7}{|c|}{ Case Processing Summary } \\
\hline & \multicolumn{6}{|c|}{ Cases } \\
\hline & \multicolumn{2}{|c|}{ Valid } & \multicolumn{2}{|c|}{ Missing } & \multicolumn{2}{|c|}{ Total } \\
\hline & $\mathrm{N}$ & Percent & $\mathrm{N}$ & Percent & $N$ & Percent \\
\hline $\begin{array}{l}\text { Yearofexperience } \\
\text { presentmethod }\end{array}$ & 110 & $99.1 \%$ & 1 & $0.9 \%$ & 111 & $100.0 \%$ \\
\hline
\end{tabular}




\begin{tabular}{|c|c|c|c|}
\hline \multicolumn{4}{|l|}{ Chi-Square Tests } \\
\hline & Value & df & $\begin{array}{l}\text { Asymp. Sig } \\
\text { (2-sided) }\end{array}$ \\
\hline Pearson Chi-Square & $12.539^{\mathrm{a}}$ & 9 & .185 \\
\hline Likelihood Ratio & 14.824 & 9 & .096 \\
\hline $\begin{array}{l}\text { Linear-by-Linear } \\
\text { Association }\end{array}$ & 1.276 & 1 & .259 \\
\hline $\mathrm{N}$ of Valid Cases & 110 & & \\
\hline \multicolumn{4}{|c|}{$\begin{array}{l}\text { a. } 7 \text { cells }(43.8 \%) \text { have expected count less than } 5 \text {. The } \\
\text { minimum expected count is } .57 \text {. }\end{array}$} \\
\hline
\end{tabular}

\begin{tabular}{|c|c|c|c|c|c|c|}
\hline \multicolumn{7}{|c|}{ Yearofexperience * presentmethodCrosstabulation } \\
\hline \multicolumn{7}{|l|}{ Count } \\
\hline & & \multicolumn{4}{|c|}{ Presentmethod } & \multirow[t]{2}{*}{ Total } \\
\hline & & $\begin{array}{l}\text { highly } \\
\text { satisfied }\end{array}$ & satisfied & dissatisfied & $\begin{array}{l}\text { highly } \\
\text { dissatisfied }\end{array}$ & \\
\hline \multirow{4}{*}{$\begin{array}{l}\text { Yearofexperiep } \\
\text { ce }\end{array}$} & $0-2$ years & 18 & 8 & 6 & 0 & 32 \\
\hline & $3-5$ years & 14 & 14 & 11 & 4 & 43 \\
\hline & $6-8$ years & 12 & 8 & 5 & 1 & 26 \\
\hline & 8 above & 3 & 4 & 0 & 2 & 9 \\
\hline \multicolumn{2}{|l|}{ Total } & 47 & 34 & 22 & 7 & 110 \\
\hline
\end{tabular}

\section{Interpretation}

The worth is essentialness (2-followed) is 0.185 which lesser than 0.05 at $95 \%$ certainty level so dismiss the invalid speculation (H0) and acknowledge the substitute theory (H1). There is affiliation contrast between the age gathering of workers as for upgrade the sentiment about the present technique pursued by the association.

\section{ii. One Way Anova}

$\mathbf{H o}=$ There is no significant different between the gender in employees with respected to enhance the opinion about the procedure followed in recruitment process.

$\mathbf{H}_{1}=$ There is significant different between the gender of employees with respected the opinion about the procedure followed in recruitment process.

One way anova association difference between the gender of employees with respected to enhance the procedure followed in recruitment process.

\begin{tabular}{|c|c|c|c|c|c|c|c|c|}
\hline \multicolumn{9}{|c|}{ Descriptives } \\
\hline \multicolumn{9}{|c|}{ Educationalqualification } \\
\hline & \multirow[t]{2}{*}{$\mathrm{N}$} & \multirow[t]{2}{*}{ Mean } & \multirow[t]{2}{*}{$\begin{array}{l}\text { Std. } \\
\text { Deviation }\end{array}$} & \multirow[t]{2}{*}{\begin{tabular}{|l|} 
Std. \\
Error
\end{tabular}} & \begin{tabular}{|l|}
$95 \%$ \\
Interval
\end{tabular} & $\begin{array}{l}\text { Confidence } \\
\text { Mean }\end{array}$ & \multirow[t]{2}{*}{$\begin{array}{l}\text { Minim } \\
\text { um }\end{array}$} & \multirow[t]{2}{*}{\begin{tabular}{|l} 
Maxim \\
um
\end{tabular}} \\
\hline & & & & & $\begin{array}{l}\text { Lower } \\
\text { Bound }\end{array}$ & $\begin{array}{l}\text { Upper } \\
\text { Bound }\end{array}$ & & \\
\hline $\begin{array}{l}\text { veryuse } \\
\text { ful }\end{array}$ & 76 & 1.72 & .858 & .098 & 1.53 & 1.92 & 1 & 4 \\
\hline useful & 23 & 1.87 & .968 & \begin{tabular}{|l|}
.202 \\
\end{tabular} & 1.45 & 2.29 & 1 & 4 \\
\hline $\begin{array}{l}\text { Adequa } \\
\text { te }\end{array}$ & 7 & 1.86 & .690 & .261 & 1.22 & 2.50 & 1 & 3 \\
\hline poor & 4 & 1.50 & 1.000 & .500 & -.09 & 3.09 & 1 & 3 \\
\hline Total & 110 & 1.75 & .869 & .083 & 1.59 & 1.92 & 1 & 4 \\
\hline
\end{tabular}

\begin{tabular}{|l|l|l|l|l|l|}
\hline ANOVA \\
\hline & $\begin{array}{l}\text { Sum of } \\
\text { Squares }\end{array}$ & If & $\begin{array}{l}\text { Mean } \\
\text { Educationalqualification }\end{array}$ & F & Sig. \\
\hline $\begin{array}{l}\text { Setween } \\
\text { Groups }\end{array}$ & .710 & 3 & .237 & .307 & .820 \\
\hline Within Groups & 81.663 & 106 & .770 & & \\
\hline Total & 82.373 & 109 & & & \\
\hline
\end{tabular}

\section{Interpretation:}

The Value Is Significance (2-Tailed) Is 0.820 Which Lesser Than 0.05 At 95\% Confidence Level So Reject The Null Hypothesis (H0) And Accept The Alternate Hypothesis (H1). Hence There Is Association Difference Between The Age Group Of Employees With Respect To The Opinion About The Present Method Followed By The Organization

\section{LIMITATIONS}

This is presented to the reason and inclinations of the respondents, in this manner $100 \%$ of precision can't be assured. The research was done in a constrained ability to center time, where in the assessment couldn't widen the study. The revelations rely upon the fitting reactions given by the laborers, so any error or inclination may be impact the authenticity of the finding.[21]-[25]

\section{CONCLUSION}

The research was carried out to provide a clear picture to identify the skills knowledge company of the employee and to match of mop them as necessary with their respective job designation. While selecting the candidate to organizations gives importance to marketing knowledge, communication skills and experience of the candidate in the respect field. The employee ready to refer their known ones to the company and they are rewarded by the management. The private organizations maintains good employee relation by conducting various recreation activities and giving them preference by awarding them for their activates.

\section{REFERENCES}

1. Vasanthi, S. \& Rabiyathul Basariya, S. 2019, "Influence of value analysis and cross training in industry", International Journal of Engineering and Advanced Technology, vol. 8, no. 6, pp. 1810-1811.

2. Velvizhi, R., Sri Gowtham, S. \& Jeya Priya, D. 2019, "Examination of early feedbacks for effective product retailing on E-commerce websites", International Journal of Engineering and Advanced Technology, vol. 8, no. 6 Special Issue 2, pp. 703-706.

3. Anuradha, C., Pothumani, S. \& Kavitha, R. 2019, "A novel method towards E-commerce", International Journal of Engineering and Advanced Technology, vol. 8, no. 6 Special Issue 2, pp. 535-538.

4. Thomas, J. \& Rabiyathul Basariya, S. 2019, "A study on the issues of financial ratio analysis", Indian Journal of Public Health Research and Development, vol. 10, no. 3, pp. 1079-1081. 
5. Ramachandran, S. \& Rabiyathul Basariya, S. 2019, "Online marketing study on customer satisfaction and relationship", Indian Journal of Public Health Research and Development, vol. 10, no. 3, pp. 1072-1078.

6. Priya, R., Vinothini, G. \& Cor Jesu, C.D. 2019, "The mentor-protégé relationship for professional growth", Journal of Advanced Research in Dynamical and Control Systems, vol. 11, no. 9 Special Issue, pp. 1110-1119.

7. Jannifer Rani, N., Bina Pani, S. \& Nimisha, N.S. 2019, "A study on money back polices available in LIC", Journal of Advanced Research in Dynamical and Control Systems, vol. 11, no. 9 Special Issue, pp. 833-839.

8. Saillaja, V., Jhansi Rani, K. \& Catherine, R. 2019, "Global marketing management planning and organization", Journal of Advanced Research in Dynamical and Control Systems, vol. 11, no. 9 Special Issue, pp. 489-493

9. Saillaja, V., Jhansi Rani, K. \& Catherine, R. 2019, "The new phase of marketing information system", Journal of Advanced Research in Dynamical and Control Systems, vol. 11, no. 9 Special Issue, pp. 482-488.

10. Thoufiqulla \& Raju, D.V. 2019, "Perception of indian investor towards investment in mutual funds with special reference to mip funds", Journal of Advanced Research in Dynamical and Control Systems, vol. 11, no. 5, pp. 177-183.

11. Jasmine, K.R.M. \& Basariya, S.R. 2018, "A study on the customers benefits on mutual funds", International Journal of Civil Engineering and Technology, vol. 9, no. 4, pp. 45-48.

12. Vasanthi, S. \& Basariya, S.R. 2019, "Pros and cons of on the job training versus off the job training", International Journal of Scientific and Technology Research, vol. 8, no. 10, pp. 671-674.

13. Pavithra, J. \& Ganesan, M. 2016, "A study on awareness and impact of micro-financial schemes", International Journal of Applied Business and Economic Research, vol. 14, no. 8, pp. 5449-5460.

14. Pavithra, J., Dilli Babu, P. \& Ambuli, T.V. 2014, "A study on budgetary control at Maruti Service Masters, Chennai", International Journal of Applied Business and Economic Research, vol. 12, no. 2, pp. 151-161.

15. Gunaraja, T.M. \& Venkatrama Raju, D. 2018, "Determining factors of organisational climate with reference to leadership styles", International Journal of Mechanical Engineering and Technology, vol. 9, no. 9, pp. 1327-1332.

16. Gunaraja, T.M. \& Venkatrama Raju, D. 2018, "The role of job satisfaction and training of employees in determining organisational climate of a selected industry", International Journal of Civil Engineering and Technology, vol. 9, no. 8, pp. 1266-1269.

17. Aarathy, T.S. \& Raju, D.V. 2018, "Performance appraisal and its effects on employees with respect to it sector in Chennai city", International Journal of Civil Engineering and Technology, vol. 9, no. 6, pp. 1535-1538.

18. Aarathy, T.S. \& Raju, D.V. 2018, "Employee perception towards performance appraisal system in IT sector", International Journal of Mechanical Engineering and Technology, vol. 9, no. 5, pp. 131-135.

19. Porselvi, W., Jublee, D. \& Sivanesan, G. 2018, "A study on factors influencing adoption of technology and innovation in banking industry, tamilnadu, India", International Journal of Mechanical Engineering and Technology, vol. 9, no. 5, pp. 789-800.

20. Akessa, G.M. and Dhufera, A.G., 2015. Factors That Influences Students Academic Performance: A Case of Rift Valley University, Jimma Ethiopia. Journal of Education and Practice, 6(22), pp.55-63.

21. Miller, G. and Shih, C.C., 1999. A faculty assessment of the academic rigor of on-and off-campus courses in agriculture. Journal of Agricultural Education, 40, pp.57-65.

22. Tsinidou, M., Gerogiannis, V. and Fitsilis, P., 2010. Evaluation of the factors that determine quality in higher education: an empirical study. Quality Assurance in education, 18(3), pp.227-244.

23. Farooq, M.S., Chaudhry, A.H., Shafiq, M. and Berhanu, G., 2011. Factors affecting students' quality of academic performance: a case of secondary school level. Journal of quality and technology management, 7(2), pp.1-14.

24. Fitsilis, P., Gerogiannis, V. and Anthopoulos, L., 2014. Ontologies for software project management: a review. Journal of Software Engineering and Applications, 7(13), p.1096.

25. Adams, J.D. and Jaffe, A.B., 1996. Bounding the effects of R\&D: an investigation using matched establishment-firm data(No. w5544) National bureau of economic research.

\section{AUTHORS PROFILE}

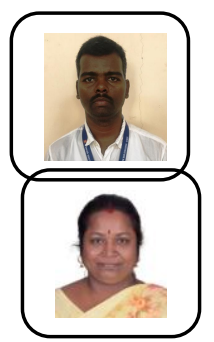

M. Sankar, Assistant Professor, Department Of Science and Humanities, Bharath Institution Of Higher Education And Research, TamilNadu, India

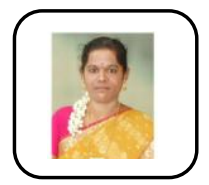

G. Anadhi, Assistant Professor, Department Of Science and Humanities, Bharath Institution Of Higher Education And Research TamilNadu, India

R. Vasuki, Assistant Professor, Department Of Science and Humanities, ,Bharath Institution Of Higher Education And Research TamilNadu, India 